DOI: $10.18276 /$ sip.2016.43/1-19

\title{
Roman Tylżanowski*
}

Uniwersytet Szczeciński

\section{KOMPETENCJE PRACOWNIKÓW A PROCESY TRANSFERU TECHNOLOGII W PRZEDSIĘBIORSTWACH PRZEMYSŁOWYCH WYSOKIEJ TECHNIKI W POLSCE}

\begin{abstract}
STRESZCZENIE
W dzisiejszych czasach podstawą funkcjonowania przedsiębiorstw są innowacje i nowoczesne technologie, które stymulują tempo rozwoju całej gospodarki. Nieustanny postęp technologiczny skłania do poszukiwania technologicznych rozwiązań bądź dzielenia się nimi z innymi podmiotami. Procesy transferu technologii odgrywają szczególną rolę w przedsiębiorstwach cechujących się wysokim potencjałem technologicznym oraz odpowiednimi kwalifikacjami zatrudnionych pracowników. Do takiej grupy podmiotów należą przedsiębiorstwa przemysłowe wysokiej techniki. Przeprowadzone badania potwierdzają, iż wysokie kompetencje pracowników są bardzo istotną determinantą procesów pozyskiwania i/lub przekazywania technologii w przemyśle wysokiej techniki.
\end{abstract}

Słowa kluczowe: transfer technologii, kompetencje, sektor wysokiej techniki

\section{Wprowadzenie}

Rozwój współczesnych przedsiębiorstw jest determinowany nie tylko dotychczasowymi osiągnięciami, ale przede wszystkim przyszłymi działaniami związanymi z pozyskiwaniem oraz absorbowaniem nowoczesnych technologii. Zmiany w zakresie technologii oraz sposobów jej transferu coraz silniej oddziałują na procesy

\footnotetext{
* E-mail: romtyl@poczta.onet.pl
} 
zachodzące w gospodarce, zarówno w wymiarze globalnym, jaki i krajowym oraz regionalnym. Sektorem gospodarki, który cechuje się wysokim poziomem innowacyjności oraz skłonnością do transferowania innowacyjnych rozwiązań, jest przemysł wysokiej techniki. W firmach należących do tego sektora uzyskiwanie przewagi konkurencyjnej coraz częściej opiera się nie tylko na wyposażeniu w innowacyjne technologie, ale również na wysokim poziomie kompetencji zatrudnionej kadry pracowniczej. Celem opracowania jest zbadanie wpływu kompetencji pracowników na procesy transferu technologii w przedsiębiorstwach przemysłowych wysokiej techniki w Polsce. W artykule uwzględniono m.in.: wskazanie istoty procesów transferu technologii, podkreślenie znaczenia tych procesów w przemyśle wysokiej techniki, a także zbadanie wpływu kompetencji pracowników badanych przedsiębiorstw na przekazanie i/lub pozyskanie technologicznych rozwiązań. W badaniu posłużono się modelowaniem ekonometrycznym z dychotomiczną zmienną zależną typu probit.

\section{Istota procesów transferu technologii}

Technologia jest obecnie jednym z najistotniejszych czynników rozwoju gospodarczego i wzrostu innowacyjności, zwłaszcza w przemyśle. Jak wskazuje K. Santarek (2008, s. 7), jest ona procesem, który składa się z wielu działań, realizowanych w ściśle określony sposób oraz w odpowiedniej kolejności, doprowadzających do przetworzenia dóbr wejściowych w spełniające potrzeby odbiorców wyroby gotowe. Odpowiednia technologia oraz skuteczne jej wdrożenie może decydować o tempie rozwoju poszczególnych przedsiębiorstw oraz zapewniać im osiągnięcie i utrzymanie przewagi konkurencyjnej na rynku. Należy mieć na uwadze, że nie każdy podmiot jest w stanie tworzyć innowacyjne rozwiązania. Liderem technologii są zazwyczaj przedsiębiorstwa, które funkcjonują w działach gospodarki charakteryzujących się ponoszeniem wysokich nakładów na badania i rozwój (B+R). Przedsiębiorstwa rozpoczynające swoją działalność często mają utrudniony dostęp do kapitału i są zmuszone do pozyskiwania i adaptowania dotychczasowych, sprawdzonych rozwiązań. Można zatem stwierdzić, że niezwykle istotną rolę odgrywają w dzisiejszych czasach procesy transferu technologii.

Transfer technologii jest pojęciem wielokrotnie i bardzo szeroko interpretowanym. J. Prystrom (2012, s. 88) wskazuje, że składa się on z działań dostosowujących badania naukowe, patenty lub oryginalne pomysły do ich praktycznego zastosowania. Priorytetem wyżej wymienionych zadań jest zatem przekazywanie wiedzy 
oraz umiejętności i zastosowanie ich w ramach prowadzonej działalności, m.in. w procesach produkcyjnych. Ostatecznym i najważniejszym zadaniem, będącym sednem transferu, jest urynkowienie powstałego w ramach tych procesów produktu. P. Głodek i M. Gołębiowski (2006, s. 53) podkreślają z kolei, iż charakterystyczną cechą procesów transferu technologii jest przekazywanie niezbędnych informacji, przyjmujących postać techniczną (wiedza naukowa, inżynierska) i/lub procedur (licencje, umowy o zachowaniu poufności). Technologia może być zatem transferowana pod postacią produktów, maszyn lub urządzeń (ucieleśniony poziom wiedzy), ale również w postaci patentów lub know-how (nieucieleśniony poziom wiedzy) (Sobczak, 2005, s. 13). Przedmiotem transferu może być z kolei wiedza, zarówno materialna, jak i niematerialna.

Należy jednak wspomnieć o tym, że transfer technologii rozpatrywać trzeba zarówno z punktu widzenia dawcy, jak i biorcy technologii. Omawiane procesy mają zatem charakter dwustronny, albowiem mogą się odbywać dwukierunkowo. W zakres transferu wchodzą procesy przekazywania technologicznych rozwiązań oraz procesy ich pozyskiwania. Innymi słowy, celem transferu technologii jest wymiana wiedzy pomiędzy podmiotami ją dostarczającymi a tymi, które zgłaszają na nią zapotrzebowanie. Role obydwóch podmiotów transferu są równie istotne. Dostarczyciel technologii przekazuje prawa autorskie do transferowanego przedmiotu w oparciu o wynegocjowane i zawarte w umowie warunki, a nabywca technologii oczekuje instrukcji do wdrożenia pozyskanych rozwiązań i zastosowania ich w praktyce, oferując w zamian odpowiednie wynagrodzenie (Prystrom, 2012, s. 90). Podmiotami transferu mogą być nie tylko przedsiębiorstwa, ale również szkoły wyższe i inne ośrodki naukowo-badawcze oraz instytucje otoczenia biznesu. Podstawą procesów transferu technologii jest z kolei współdziałanie z innymi podmiotami (Gwarda-Gruszczyńska, 2004, s. 106).

Wspomniany wcześniej praktyczny aspekt transferu technologii wskazuje, iż procesy transferu nie kończą się w momencie zakupu technologicznych rozwiązań. Samo pozyskanie nie daje bowiem gwarancji, że zakupiona nawet na najlepszych warunkach technologia zostanie skomercjalizowana i przyniesie sukces w postaci przychodów ze sprzedaży, a w dłuższej perspektywie czasowej przewagę konkurencyjną. Podkreślenia wymaga zatem istotny etap transferu, jakim jest absorpcja pozyskanej technologii. Podmiot nabywający technologię powinien pozyskać również odpowiednią wiedzę, niezbędną do prawidłowego wykorzystania technologicznych rozwiązań, a także dopasować ją do warunków panujących w ramach własnej organizacji. Transferowane technologie nie są bowiem uniwersalne. Należy podjąć wysiłek 
mający na celu akomodację nabytych rozwiązań i doprowadzenie do skomercjalizowania powstałych dzięki nim produktów.

Czynnikami sprzyjającymi wzrostowi zainteresowania procesami transferu technologii są zachodzące nieustannie zmiany $\mathrm{w}$ gospodarce $\mathrm{i}$ towarzyszące tym zmianom wysokie tempo postępu technologicznego. Podmioty chcące przetrwać na tym burzliwym rynku muszą nieustannie doganiać konkurencję, m.in. poprzez oferowanie innowacyjnych produktów. Efektem podejmowanych przez konkurujące ze sobą przedsiębiorstwa działań jest chociażby przyspieszenie zachodzących w firmie procesów produkcyjnych oraz poprawa jakości dostarczanych wyrobów lub usług. Sukces przedsiębiorstwa może zapewnić właśnie pozyskanie z zewnątrz technologicznych rozwiązań. Jak wskazuje J. Wiśniewska (2015, s. 136), żaden podmiot nie dysponuje bądź nie jest w stanie samodzielnie wytworzyć całej niezbędnej wiedzy technologicznej, a dodatkowo pozyskanie jej od innych podmiotów pozwala również na skrócenie czasu poświęconego na implementację oraz ograniczyć nakłady ponoszone na działalność $\mathrm{B}+\mathrm{R}$.

Przekazywanie oraz pozyskiwanie technologii może odbywać się w sposób odpłatny lub nieodpłatny, a wykorzystać można do tego celu zróżnicowane kanały oraz mechanizmy. Niezależnie od wymienionych form transferu istotne jest, aby odbywał się on przy uwzględnieniu następujących warunków (Wiśniewska, 2009, s. 225):

- należy rozpoznać i wybrać technologie, które są dla przedsiębiorstwa niezbędne,

- konieczne jest zweryfikowanie wszystkich elementów technologii w celu zidentyfikowania, które z tych elementów mogą być pozyskane bezpośrednio, a które wymagają zaabsorbowania dodatkowej wiedzy i podjęcia działań przystosowawczych,

- należy dostosować wybrane elementy transferowanej technologii do warunków podmiotu, który ją importuje,

- konieczne jest utworzenie oraz zapewnienie najlepszych warunków, sprzyjających asymilowaniu pozyskiwanej technologii.

Powyżej przytoczone podejścia w definiowaniu omawianego zagadnienia pozwalają wyprowadzić wniosek, iż transfer technologii to proces bardzo złożony, składający się z wielu wzajemnie ze sobą powiązanych działań, do realizacji których zaangażowanych jest wiele podmiotów. Bardzo istotne jest, żeby każdy uczestnik transferu maksymalnie wykorzystał własny potencjał do tego, aby procesy przekazania oraz pozyskania technologii przebiegały w sposób sprawny oraz skuteczny. 


\section{Znaczenie kompetencji pracowników w procesach transferu technologii w przemyśle wysokiej techniki}

Wykorzystanie nowoczesnych rozwiązań technologicznych w przedsiębiorstwach przemysłowych ma przede wszystkim na celu wdrożenie w procesach produkcyjnych takich zasad postępowania, które pozwolą na osiągnięcie zamierzonych rezultatów, poprzez zaangażowanie jak najniższych nakładów oraz dostarczanie jak najwyższej jakości produktów. Czynnikiem sprzyjającym sprawnej realizacji tych procesów są wysokie kwalifikacje i kompetencje zatrudnionych w przedsiębiorstwie pracowników.

Badanie znaczenia tego czynnika oraz jego wpływu na procesy transferu technologii przeprowadzono na próbie 309 przedsiębiorstw przemysłowych funkcjonujących w Polsce, które należą do sektora wysokiej techniki. Wykorzystano do tego celu kwestionariusz ankietowy, który posłużył do pozyskania informacji na temat czynników determinujących procesy transferu technologii w latach 2008-2013.

Badany sektor bywa zamiennie nazywany sektorem wysokiej/zaawansowanej technologii bądź sektorem high-tech (Zakrzewska-Bielawska, 2011, s. 20). Bazując na dziedzinowej klasyfikacji działalności polskich podmiotów gospodarczych, opublikowanej w dokumencie NaceRev. 2. Statistical classification of economic activites in the European Community (2008), w skład badanego sektora wchodza przedsiębiorstwa:

- produkujące podstawowe substancje farmaceutyczne oraz leki i pozostałe wyroby farmaceutyczne,

- produkujące komputery, wyroby elektroniczne i optyczne,

- produkujące statki powietrzne, kosmiczne i podobne maszyny.

Wybór podmiotu badawczego podyktowany był faktem, iż w sektorze tym ponoszone są wysokie, w porównaniu do przeciętnych, nakłady na działalność badawczo-rozwojową (B+R), a jednocześnie udział pracowników naukowo-badawczych zatrudnionych w przedsiębiorstwach przemysłowych wysokiej techniki jest zazwyczaj wyższy niż w pozostałych przedsiębiorstwach przemysłowych. Wynika z tego, iż w przemyśle zaawansowanych technologii wykorzystywane są przede wszystkim najnowsze osiągnięcia naukowe, techniczne oraz technologiczne. Dodatkowo przedsiębiorstwa sektora high-tech cechują się także m.in. wysokim poziomem innowacyjności, wysoką intensywnością techniczną, szybką dyfuzją innowacyjnych rozwiązań, wyposażeniem w nowoczesne maszyny i urządzenia oraz wysoką skłonnością do współpracy z innymi podmiotami (Wojnicka, Klimczak, Wojnicka, Dąbkowski, 
2006, s. 7). Powyższa charakterystyka podmiotu badawczego pozwala przypuszczać, iż posiadane przez zatrudnionych pracowników kompetencje i kwalifikacje powinny mieć w sektorze high-tech bardzo istotne znaczenie.

Z przeprowadzonej wśród kierowników przedsiębiorstw przemysłowych wysokiej techniki ankiety wynika, iż poziom kompetencji kadry pracowniczej w procesach transferu technologicznych rozwiązań ma dla badanych podmiotów istotne znaczenie, albowiem ponad 70\% firm deklaruje, iż zatrudnieni w nich pracownicy posiadają kompetencje do samodzielnego wdrażania nowoczesnych technologii. Nieznacznie mniejszy jest udział przedsiębiorstw, w których pracownicy posiadają wystarczające kompetencje, aby samodzielnie projektować nowe rozwiązania technologiczne. Przedstawione poniżej wyniki potwierdzają zatem, że badane przedsiębiorstwa aktywnie włączają się w procesy powstawania nowych technologii (rys. 1). Dzięki wysokim kompetencjom pracowników firmy sektora high-tech są w stanie lepiej zaspokajać potrzeby odbiorców. Można przypuszczać również, iż nie tylko kadrze kierowniczej zależy na wysokim poziomie kompetencji zatrudnionych osób. Wciąż wysoki poziom bezrobocia jest czynnikiem determinującym pracowników przedsiębiorstw do nieustannego podnoszenia swoich kwalifikacji.

Rysunek 1. Udział przedsiębiorstw przemysłowych sektora wysokiej techniki w Polsce pod względem posiadanych przez pracowników kompetencji do samodzielnego projektowania bądź wdrażania technologii

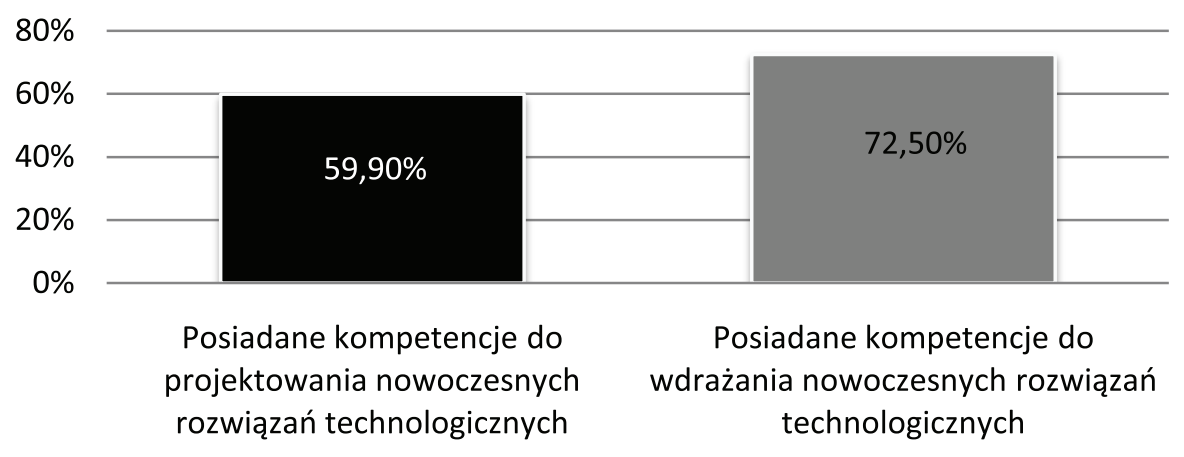

Źródło: Opracowanie własne na podstawie badań. 
Postanowiono zweryfikować również, jak istotnym czynnikiem w procesach transferu technologii jest dla badanych przedsiębiorstw posiadanie kompetentnej i wykwalifikowanej kadry pracowniczej.

Rysunek 2. Istotność kompetencji i kwalifikacji pracowników w procesach transferu technologii w przedsiębiorstwach przemysłowych wysokiej techniki w Polsce

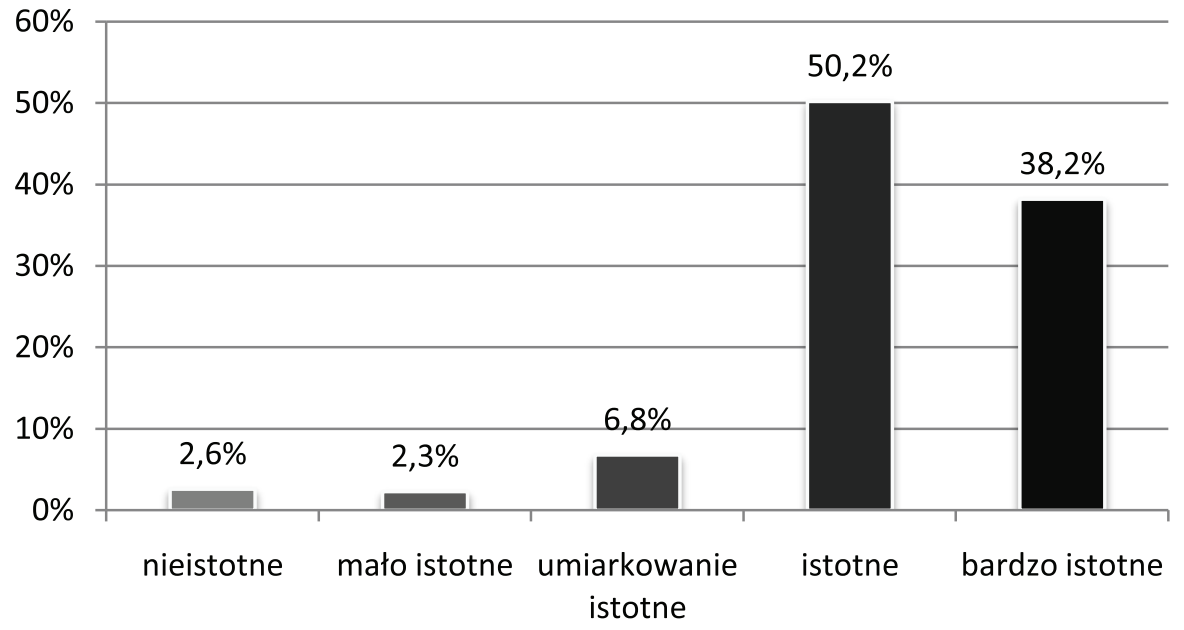

Źródło: Opracowanie własne na podstawie badań.

Jak wskazują wyniki zaprezentowane na rysunku 2, przedsiębiorstwa doceniają znaczenie czynnika ludzkiego w procesach przekazania lub pozyskania technologicznych rozwiązań. Prawie 90\% przedsiębiorstw należących do próby badawczej stwierdziło bowiem, iż kompetencje zatrudnionych pracowników są dla nich istotne lub bardzo istotne.

\section{Wpływ kompetencji pracowników przedsiębiorstw przemysłowych wysokiej techniki na procesy transferu technologii}

Wykorzystanie wysokich technologii wpływa na realizowane przez pracowników badanych przedsiębiorstw zadania. $Z$ tego względu firmy są zainteresowane zatrudnianiem ludzi o pożądanych predyspozycjach zawodowych. Postanowiono zweryfikować, jaki wpływ na procesy transferu technologii zachodzące w sekto- 
rze high-tech (zmienna zależna) mają kompetencje pracowników do samodzielnego projektowania lub wdrażania nowoczesnych rozwiązań technologicznych (zmienna niezależna). Wszystkie wykorzystane w badaniu zmienne miały charakter binarny, co oznacza, że mogły przyjmować dwa warianty odpowiedzi. Zdecydowano się na zastosowanie modelowania ekonometrycznego z dychotomiczną zmienną zależną typu probit. Wykorzystane w modelu parametry oszacowano za pomocą metody największej wiarygodności (MNW), polegającej na wyznaczeniu ocen parametrów modelu z próby (Welfe, 1998, s. 73-76). Istotne statystycznie modele zamieszczono w tabeli 1, w której uwzględniono również dodatkowe oznaczenia:

- BłSt - standardowy błąd prognozy,

- $\mathrm{P}_{1}$ - prawdopodobieństwo wystąpienia zdarzenia w badanej grupie przedsiębiorstw,

- $\mathrm{P}_{2}$ - prawdopodobieństwo wystąpienia zdarzenia w pozostałych przedsiębiorstwach.

Wszystkie spośród uzyskanych istotnych statystycznie modeli posiadały znak dodatni, co oznacza, że zamieszczone poniżej wyniki należy interpretować w ten sposób, iż prawdopodobieństwo przekazania bądź pozyskania technologicznych rozwiązań było w tej grupie przedsiębiorstw większe niż w pozostałej zbiorowości. Można więc stwierdzić, że analizowany czynnik pozytywnie wpływa na transfer technologii w badanych podmiotach.

W przedsiębiorstwach zatrudniających pracowników kompetentnych w zakresie samodzielnego projektowania nowych technologii prawdopodobieństwo przekazania technologii jest o $80 \%$ większe niż w pozostałych firmach. Największe szanse (ponad dwa razy większe w porównaniu do innych przedsiębiorstw) dotyczą udzielenia licencji, pozyskania technologii w formie know-how, publikacji informacji o technologii, nieformalnego kontaktu z naukowcami oraz udziału w konferencji naukowej. Kompetencje pracowników zwiększają zatem szanse na tworzenie nowych rozwiązań, które będą mogły zostać skomercjalizowane. 
Tabela 1. Modele probitowe transferu technologii w przedsiębiorstwach przemysłowych wysokiej techniki w Polsce - zmienna niezależna „kompetencje pracowników do samodzielnego projektowania bądź wdrażania nowoczesnych rozwiązań technologicznych"



Źródło: Opracowanie własne na podstawie badań. 
Szansę na zaistnienie transferu technologii zwiększają także posiadane przez pracowników przemysłu wysokiej techniki kompetencje do samodzielnego wdrażania nowoczesnych technologii. Prawdopodobieństwo sprzedaży maszyn i urządzeń technicznych zwiększa się około dwukrotnie. Firmy są zainteresowane zakupem zmaterializowanej technologii lub licencji, albowiem są w stanie samodzielnie zaimplementować pozyskane rozwiązania technologiczne i wykorzystać je na własne potrzeby. Nieodpowiednia kadra pracownicza może nie być wystarczająco przygotowana na samodzielne przyjęcie technologii. Skorzystanie z zewnętrznych usług wdrożeniowych bywa $\mathrm{z}$ kolei bardzo kosztowne. W związku z powyższym podmioty te bardzo często rezygnują z pozyskania technologicznych rozwiązań. W przypadku przedsiębiorstw przemysłowych wysokiej techniki prawdopodobieństwo pozyskania technologii poprzez zakup praw jest prawie trzy razy większe niż w innych firmach. Do prowadzenia działalności w badanych podmiotach potrzebni są przede wszystkim pracownicy, którzy potrafią w odpowiedni sposób obsługiwać technologie. Niezbędne mogą być również umiejętności do skutecznej implementacji pozyskanych technologii, czyli dostosowania ich do warunków panujących w konkretnym przedsiębiorstwie.

\section{Podsumowanie}

Przeprowadzone badania i zamieszczone w opracowaniu wyniki pozwalają na stwierdzenie, iż kwalifikacje i kompetencje kadry pracowniczej przedsiębiorstw przemysłowych wysokiej techniki odgrywają kluczową rolę w tworzeniu innowacyjnych produktów, a jednocześnie determinują powodzenie procesów przekazania i/lub pozyskania technologicznych rozwiązań. Trzeba mieć jednak na uwadze, iż ważne są nie tylko kompetencje do samodzielnego projektowania oraz wdrażania technologii, ale również nieustanne monitorowanie kierunków zmian nowych technologii oraz bieżące dostosowywanie wiedzy na ten temat do potrzeb rozwojowych firmy.

\section{Literatura}

Głodek, P., Gołębiowski, M. (2006). Transfer technologii w małych i średnich przedsiębiorstwach. Warszawa: Vademecum Innowacyjnego Przedsiębiorstwa.

Gwarda-Gruszczyńska, E. (2004). Myślenie strategiczne w przedsiębiorstwie o poszerzonych granicach wertykalnych. W: Z. Olesiński, A. Szplik (red.), Przedsiębiorstwo i region w zjednoczonej Europie. Kielce: Wyd. Akademii Świętokrzyskiej w Kielcach. 
NaceRev. 2. Statistical classification of economic activites in the European Community (2008).

Prystrom, J. (2012). Innowacje w procesie rozwoju gospodarczego. Istota i uwarunkowania. Warszawa: Difin.

Santarek, K. (2008). Transfer technologii z uczelni do biznesu. Tworzenie mechanizmów transferu technologii. Warszawa: PARP.

Sobczak, D. (2005). Transfer technologii oraz narodowy system innowacji. Problemy Jakości, 7.

Welfe, E. (1998). Ekonometria. Warszawa: PWE.

Wiśniewska, J. (2009). Technologia i procesy jej transferu w działalności przedsiębiorstw. W: W. Janasz (red.), Innowacje w strategii rozwoju organizacji Unii Europejskiej. Warszawa: Difin.

Wiśniewska, J. (2015). Technologia jako strategiczny czynnik innowacyjności organizacji. W: J. Wiśniewska, K. Janasz (red.), Innowacje i procesy transferu technologii w strategicznym zarządzaniu organizacjami. Warszawa: Difin.

Wojnicka, E., Klimczak, P., Wojnicka M., Dąbkowski, J. (2006). Perspektywy rozwoju matych i średnich przedsiębiorstw wysokich technologii w Polsce do 2020 roku. Warszawa: PARP.

Zakrzewska-Bielawska, A. (2011). Relacje między strategia a struktura organizacyj$n q$ w przedsiębiorstwach sektora wysokich technologii. Łódź: Wyd. Politechniki Łódzkiej.

\title{
COMPETENCES OF ENTERPRISES AND TECHNOLOGY TRANSFER PROCESSES IN HIGH-TECH MANUFACTURING SECTOR
}

\begin{abstract}
Nowadays innovations and modern technologies are the basis for the functioning of enterprises. They stimulate growth rate of the whole economy. Constant technological progress tends to seek or share technological solutions with other entities. Technology transfer processes play a special role in the enterprise, characterized by a high technological potential and relevant qualifications of employees. Empirical studies confirm that competences are a very important determinant of the processes of acquisition and/or transfer of technology in high-tech manufacturing sector.
\end{abstract}

Translated by Roman Tylżanowski

Keywords: technology transfer, competences, high-tech manufacturing sector

Kody JEL: O14, O31 